\title{
EL MUNDO SE RESQUEBRAJA. LA PERCEPCIÓN CHILENA DE LAS REVOLUCIONES DE EUROPA ORIENTAL EN 1989
}

\section{THE WORLD IS CRACKING. THE CHILEAN PERCEPTION OF THE REVOLUTIONS OF EASTERN EUROPE IN 1989}

\author{
Froilán Ramos Rodríguez*1, Constanza Arias Arias $^{2}$ \\ ${ }^{1}$ Universidad Católica de la Santísima Concepción (UCSC), Concepción. Chile \\ ${ }^{2}$ Universidad de Las Américas. Santiago. Chile
}

\begin{abstract}
RESUMEN: Este trabajo analiza la percepción de las revoluciones de Europa Oriental de 1989 a través de la prensa chilena, en el contexto del proceso de cambio político que vivía Chile en aquel momento. La investigación se apoya en la revisión crítica de diversos medios contemporáneos: diarios, revistas, testimonios escritos, que permiten aproximarse al impacto producido en la esfera pública, los actores políticos y medios de comunicación. Las revoluciones de 1989 conllevaron a la caída de los gobiernos comunistas en diversos países europeos, que consiguientemente repercutieron en el fin de la Guerra Fría y de la Unión Soviética.
\end{abstract}

PALABRAS CLAVES: Revolución, 1989, Europa Oriental, Chile.

ABSTRACT: This paper analyzes the perception of the Eastern European revolutions of 1989 through the Chilean press, in the context of the process of political change that Chile was experiencing at that time. The research relies on the critical review of various contemporary media: newspapers, magazines, and written testimonials, which allow us to approximate the impact produced in the public sphere, political actors and the media. The 1989 revolutions led to the fall of communist governments in various European countries, which consequently had repercussions on the end of the Cold War and the Soviet Union.

KEYWORDS: Revolution, 1989, Eastern Europe, Chile.

* Correspondencia a: Froilán Ramos Rodríguez. Universidad Católica de la Santísima Concepción. Departamento de Historia y Geografía. Campus San Andrés. Alonso de Ribera 2850, Concepción, Bio-Bio (Chile) - framos@ucsc.cl - http:// orcid.org/0000-0002-7740-9272

Cómo citar: Ramos Rodríguez, Froilán; Arias Arias, Constanza (2021). «El mundo se resquebraja. La percepción chilena de las revoluciones de Europa Oriental en 1989»; Historia Contemporánea, 65, 197-232. (https://doi.org/10.1387/hc.20756).

Recibido: 14 abril, 2019; aceptado: 12 septiembre, 2019.

ISSN 1130-2402 - eISSN 2340-0277 / (C) 2020 UPV/EHU

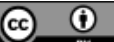

Esta obra está bajo una licencia

Creative Commons Atribución 4.0 Internacional 
La Guerra Fría era un orden terrible y amenazante, pero un orden mundial.

Arturo Uslar Pietri

«El periodismo en tiempos de crisis», 1995.

\section{Introducción}

1989 fue un año inolvidable para la memoria de la humanidad. Distintas interpretaciones se han levantado para explicar lo ocurrido aquel año de coyuntura histórica internacional, que parece al mismo tiempo tan lejana y tan cercana. A tres décadas de aquellos sucesos, que marcaron el comienzo del derrumbe del comunismo en Europa, parece oportuno hacer una revisita y revisión desde la mirada latinoamericana, en especial de la prensa chilena sobre los hechos, a fin de aproximarse a cómo se percibieron los cambios políticos en Europa del Este y considerar las implicancias a nivel local.

A la luz del tiempo, son muchas las interrogantes que se han tejido en torno al tema, en particular por el contexto chileno de la época, lo que lleva a preguntarse, ¿Qué influencias tuvieron las revoluciones de 1989 en los medios de Chile? ¿Cómo fueron retratados los cambios políticos de Europa oriental en la prensa chilena? ¿Qué visiones tuvieron los actores políticos locales de aquella situación? Todas inquietudes importantes que guían este estudio en su aproximación al problema.

La hipótesis de trabajo considera que la prensa chilena percibió las revoluciones de Europa oriental, en particular la alemana, como un símil del proceso que vivía el país, es decir, de cambio político, pero bajo distintas perspectivas. Para algunos medios conservadores, se demostraba que Chile cambiaba de forma ordenada, mientras que, para los medios de izquierda, los cambios en Europa del Este eran producto del reformismo socialista soviético.

De este modo, el objetivo central del estudio es analizar el relato construido en la prensa escrita chilena en torno a las revoluciones de $\mathrm{Eu}-$ ropa oriental de 1989. De manera específica, explicar y comparar las diferentes posturas editoriales asumidas por los principales diarios y revistas chilenos de la época sobre aquellos cambios políticos en el antiguo bloque del Este europeo.

En la actualidad, existe una nutrida literatura sobre las revoluciones de 1989 y el término de la Guerra Fría, encontrándose textos escritos 
desde distintas perspectivas. Entre ellas, sobresalen las historias enfocadas en aquel conflicto, como la de John Lewis Gaddis ${ }^{1}$, Ronald Powaski ${ }^{2}$, Odd Arne $\mathrm{Westad}^{3}$, entre otros; las producciones especializadas en handbooks ${ }^{4}$ y en revistas ${ }^{5}$ y las obras de historia contemporánea con un carácter más globalizante ${ }^{6}$. Sin embargo, el mayor desafío intelectual, teórico y metodológico desde América Latina - y desde Chile en particular- es el estudio y comprensión de estos procesos globales con ojos, miradas y percepciones latinoamericanas, es decir, las visiones de la historia mundial interpretadas por latinoamericanos y en diálogo internacional.

La historiografía chilena reciente se ha acercado al tema desde tres perspectivas. Por un lado, Joaquín Fermandois con Mundo y fin de mundo, que reúne el enfoque de la historia de las relaciones internacionales y la política exterior chilena en ese contexto ${ }^{7}$. Mientras que, por otro lado, Cristián Medina y Gustavo Gajardo han estudiado el problema a partir del caso Honecker y su exilio en Chile ${ }^{8}$, en el que integran la coyuntura internacional y la realidad chilena en este proceso contemporáneo. Ambos trabajos resultan un valioso apoyo a este estudio por contribuir a la interconexión entre lo mundial y lo local, y la relación particular de Chile con estos acontecimientos. Una tercera mirada fue aportada por Olga Ulianova, quien estudió el problema desde la perspectiva rusa y su impacto en Chile $^{9}$, lo que representó una innovación, al poder tener acceso a documentación en idioma ruso.

En este orden, uno de los mayores retos lo constituye el acceso a las fuentes europeas orientales y los idiomas de cada país del Este europeo. No obstante, las fuentes hemerográficas chilenas ofrecen una amplia y di-

1 Gaddis, 2012.

2 Powaski, 2000.

3 Westad, 2017.

${ }^{4}$ Por ejemplo, The Cambridge History of the Cold War, 2010; The Cambridge History of Communism, 2017; The Oxford Handbook of the History of Communism, 2014; The Routledge of the Cold War, 2014.

5 Como Journal of Cold War Studies, Journal of Cold War History, East European Politics o Central \& Eastern European Review, otras.

${ }^{6}$ En Chile como en América Latina, la literatura sobre la historia contemporánea proviene, principalmente, de las ediciones españolas. Por ejemplo, Casassas, 2013; Martín de la Guardia, 2012; Villares y Bahamonde, 2012, otros.

7 Fermandois, 2004.

${ }^{8}$ Medina y Gajardo, 2017, pp. 260-284; Medina y Gajardo, 2016, pp. 731-748; Medina et al., 2018, pp. 49-60.

9 Ulianova, 2013; Ulianova y Riquelme, 2005. 
versa cantidad de periódicos y revistas, que registraron las distintas percepciones sobre los acontecimientos vividos en Europa oriental en 1989.

Metodológicamente, se seleccionaron los principales medios de comunicación escrita que circulaban en Chile para aquel año de 1989, y que resultan significativos por sus distintos enfoques editoriales. Estos medios se recabaron en las Secciones de Diarios y Microformatos y de Revistas, ambas en la Biblioteca Nacional, y también se consultaron materiales del Centro de Investigación y Documentación (CIDOC, de la Universidad Finis Terrae, Santiago). De esta manera, se recolectaron los diarios El Mercurio, La Tercera, La Segunda, La Nación, La Época y El Siglo; y las revistas Qué Pasa, Hoy, Caras y Pluma y Pincel. Estas publicaciones periódicas fueron analizadas y sometidas a crítica historiográfica para extraer los distintos testimonios recogidos en sus editoriales, reportajes periodísticos, columnas de opinión y entrevistas a dirigentes políticos.

\section{El cambio de los nuevos tiempos: los ochenta (1985-1989)}

El siglo XX se caracterizó por ser una época de conflictos. Desde 1945, el mundo se polarizó rápidamente con la Guerra Fría, donde las dos superpotencias ganadoras de la Segunda Guerra Mundial, Estados Unidos (EE. UU.) y la Unión Soviética (URSS), se disputaron la hegemonía de sus ideologías, capitalista y comunista, respectivamente.

A comienzos de la década de 1980, el comunismo internacional estaba sufriendo una fuerte crisis económica y política, reflejada especialmente en una Alemania separada por el «Telón de Acero», que representaba una diferencia en la calidad de vida entre el lado oriental y el lado occidental. Si bien la República Democrática Alemana (RDA) fue una de las economías comunistas de mayor desarrollo, esto tuvo un coste político y social elevado ${ }^{10}$. Este descontento social se sumó a los escándalos de corrupción dentro del partido comunista de la URSS, contrabando y conflicto de intereses, lo que provocó una caída exponencial en los índices de aprobación y confianza en el gobierno.

En 1985, Mijaíl Gorbachov asumió como nuevo secretario general del Partido Comunista de la URSS. Gorbachov mostró, desde un principio, su interés por generar reformas al sistema comunista, las cuales se converti-

10 Mavrokordatos et al., 2010, pp. 113-124. 
rían en parte fundamentales de su gobierno. Gorbachov introdujo la Perestroika (reestructuración), que pretendió generar importantes cambios económicos y políticos, al instalar en el sistema los elementos de: independencia comercial y autogestión financiera, cooperativas y empresas de carácter privado ${ }^{11}$.

Igualmente, Gorbachov implementó el Glasnost (transparencia), que permitió la libertad de expresión, liberación de prisioneros políticos, derecho a manifestar y reducción de la censura estatal. En su política exterior, las relaciones internacionales se abrieron a países capitalistas; el mismo Gorbachov se reunió con presidentes estadounidenses en negociaciones de acuerdos de paz. Otras decisiones controversiales fueron el desarme nuclear de la URSS y el retiro de tropas soviéticas de Afganistán, medidas que generaron un quiebre en el partido comunista soviético, entre el ala ortodoxa y Gorbachov.

A su vez, los países que se encontraban bajo el comunismo pasaron por un panorama similar. Manifestaciones sociales se llevaron a cabo en distintas partes de Europa oriental: Polonia, Hungría y la RDA; que exhibieron el descontento reinante, marcado por exigencias de mayores prestaciones y estabilidad para los ciudadanos ${ }^{12}$.

Polonia fue uno de los primeros países en revelarse contra el régimen comunista del general Wojciech Jaruselzki. Desde comienzos de la década, surgió un nuevo movimiento sindical liderado por el Sindicato Solidaridad, el cual, apoyado en la presión social contra el sistema comunista, pudo ser reconocido legalmente. En junio de 1989, el partido Comunista fue derrotado en las elecciones, quedando el país bajo el mandato de Solidaridad, en la persona Tadeusz Mazowiecki. Éste llegó a ser el primer gobierno no comunista desde 1945 en Europa Oriental, lo que desencadenó una rápida desintegración del partido comunista polaco ${ }^{13}$.

En Hungría sucedía algo particular. Siendo los mismos integrantes del partido Comunista húngaro los que intervinieron el sistema, expulsaron a Janos Kadar, antiguo dirigente, en 1988; para luego, en 1989, legalizar el multipartidismo. En octubre del mismo año, el partido Socialista Obrero Húngaro se disolvió y se aprobó una constitución de carácter democrático,

\footnotetext{
11 Ver: Gorbachov, 1987.

12 Sobre las revoluciones de 1989, ver: Tsmaneanu, 1999; Kotkin and Gross, 2009; McDermott and Stibbe, 2013, otros.

13 Sobre Polonia, ver: Kemp-Welch, 2008; Paczkowski, 2015; Del autoritarismo a la democracia: La experiencia polaca, 2014, otros.
} 
con el que, en el año 1990, las fuerzas anticomunistas democráticas ganaron el poder ${ }^{14}$. El caso de Hungría está estrechamente relacionado con la RDA, puesto que las autoridades húngaras tomaron la decisión, en 1989, de abrir las fronteras con Austria, lo que abrió una brecha en el «Telón de Acero, por donde muchos alemanes orientales emigraron hacia la zona occidental, atravesando Checoslovaquia, Hungría y Austria.

En paralelo, una serie de manifestaciones desarrolladas en la RDA plantearon un clima de descontento y revuelta social. Eric Honecker, líder comunista ortodoxo, vio la contención como una medida factible, y felicitó públicamente al embajador chino por la represión llevada a cabo en la Plaza Tiananmen ${ }^{15}$. Moscú respondió con un cambio en su tradicional postura de control: Gorbachov condenó públicamente la Doctrina Breznev, lo que derivó en la sustitución de Honecker por un comunista reformista, Egon Krenz, quien fue el responsable de la decisión de abrir el Muro de Berlín el 9 de noviembre de 1989, para luego reunificar las dos Alemanias el 3 de octubre de $1990^{16}$.

A un océano de distancia, Chile tampoco estuvo fuera del contexto de la Guerra Fría. El país suramericano había vivido también las tensiones y polarización ideológica del conflicto. A partir de 1973, un gobierno militar, encabezado por el general Augusto Pinochet, dirigía la nación, pero dadas las acusaciones de violaciones de derechos humanos, Chile había sido aislado internacionalmente desde la década de los setenta ${ }^{17}$. En 1980, se promulgó una nueva constitución, que contempló la celebración de un plebiscito en 1988. Sin embargo, en 1983 comenzaron protestas contra el gobierno, y ya para 1985 había demandas políticas para la vuelta a la democracia en el país ${ }^{18}$.

En aquellos años, el trabajo de la prensa experimentó cambios profun$\operatorname{dos}^{19}$. Durante los setenta, algunos medios de izquierda fueron cerrados, mientras que otros periódicos optaron por mantener una postura más cau-

${ }^{14}$ Sobre Hungría, ver: Bozóki, 2002; Gyarmati and Valuch, 2009; Cough, 2006, otros.

15 Fanjul, 2009, pp. 29-34.

${ }^{16}$ Sobre Alemania, ver: Fulbrook, 2000; Maier, 1997; Veen et al., 2010, otros.

17 Véase: Fermandois, 1991, pp. 433-455; Rojas, 1997, pp. 376-406, otros.

18 Ver: Huneeus, 2000, Rubio, 2013, otros.

19 Este trabajo centra su atención en los medios impresos, sin embargo, para otros medios de comunicación, como la radio, la televisión, incluso el cine documental, que también experimentaron escenarios de cambios y adaptaciones al nuevo contexto político, puede verse: Acuña, 2007; Rivera, 2008; Campos, 2016; Dittus y Ulloa, 2017, entre otros. 
telosa ${ }^{20}$. En general, los diarios chilenos se adaptaron a la nueva dinámica del régimen político imperante tomando distintas posturas, desde la colaboración hasta la mayor cobertura de noticias internacionales. Para mediados de la década de los ochenta, aparecieron nuevos medios con tendencias más generalistas, que ofrecieron otras alternativas a los diarios tradicionales, como el periódico La Época ${ }^{21}$.

El plebiscito de octubre de 1988 fue ganado por la opción del No, lo que representó el inicio del proceso de retorno a la democracia en 1989, con la negociación política para la transición y la realización de comicios presidenciales en diciembre de aquel ${ }^{22}$. De este modo, el Chile de 1989 experimentaba una etapa - todavía tímida - de apertura internacional y de regreso gradual a la democracia.

En este mismo año, en Europa se llevaban a cabo las «Revoluciones de 1989», los medios de comunicación chilenos estaban atentos al acontecer nacional e internacional, aunque la disputa entre el gobierno militar y la oposición era el tema principal de las portadas, y el temor a que no se reconocieran los resultados, opacó, en alguna medida, al acontecer internacional. Sin embargo, Chile no estuvo absorto de éstas. Si se hace un paralelismo, el acontecer chileno y el devenir europeo estaban relacionados, dada la dicotomía, el capitalismo versus el comunismo, tal como lo muestra la prensa chilena y las percepciones de ésta sobre los sucesos europeos.

\section{Las revoluciones de 1989 en los medios chilenos}

Los movimientos ciudadanos por democracia y libertades en Europa oriental hallaron eco en la prensa mundial como un hecho sin precedentes, pocas veces visto en un siglo marcado por la guerra y las ideologías. Los medios chilenos no estuvieron exentos de mirar con una mezcla de escepticismo y sorpresa los sucesos europeos. Uno a uno, país por país, la prensa chilena fue informando de las demandas populares y cambios de régimen al otro lado de la «cortina de Hierro». En poco tiempo, las «Revoluciones de Otoño» comenzaron a ocupar más centímetros de las tiradas de los diarios y revistas chilenos.

${ }^{20}$ Sobre el devenir de la prensa chilena, se puede ver: Garay Vera y Willicke, 2007; Dooner, 1989; Soto, 2003; Santa Cruz, 2015, entre otros.

21 Sobre el impacto del diario, puede verse: Ossandón y Rojas, 1989.

22 Véase: Angell, 2005, pp. 401-434. 
En un primer momento, los movimientos populares en Europa oriental parecían estar lejanos, y combinaban sorpresa y atención por los medios nacionales. En este sentido, los diarios chilenos reproducían reportajes de agencias de prensa internacionales, como AP, Reuters, AFP; con descripciones generales - en algunos casos dramáticas-, de los acontecimientos de Europa Oriental. Asimismo, en otras oportunidades también se reprodujeron artículos de análisis de medios de comunicación estadounidenses, que mostraban posibles proyecciones que podrían alcanzar los hechos acaecidos ${ }^{23}$. Esta reproducción de la información y noticias podría explicarse por las distancias y los costos para los periódicos de mantener equipos en Europa. Sin embargo, conforme avanzaban los sucesos y se incrementaba la preocupación por los movimientos democráticos, varios diarios buscaron ampliar su seguimiento de la información.

La Segunda envío un equipo especial para cubrir el viaje a los EE. UU. del líder Lech Walesa. Desde Washington, Walesa, quien participaba en el Congreso de la Federación Norteamericana del Trabajo, expresó: «necesitamos vender el $80 \%$ de nuestra economía [...]. Pero los polacos no pueden comprarlo porque son pobres» ${ }^{24}$. En ese momento, Walesa era una sensación en los medios internacionales, y desde Chile se observaba con atención cómo el dirigente polaco, católico y obrero, había logrado encabezar una transformación política y económica de forma pacífica en Polonia.

Otro personaje que suscitó la atención de los diarios chilenos, pero por razones totalmente distintas, fue el rumano Nicolae Ceausescu. En El Mercurio se señalaba: «Con Nicolae Ceausescu, el culto a la personalidad ha florecido en Rumania con vigor solamente comparable al que adquirió en la URSS de Stalin o en la China de Mao» ${ }^{25}$. El diario hizo referencia directa a que Ceausescu acababa de ser reelecto por el Partido Comunista para gobernar cinco años más, además de ser nombrado «Héroe de la Nación», justo en el momento en que habían caído varios regímenes comunistas en Europa oriental, mientras que la Rumania de Ceausescu parecía inalterada.

${ }^{23}$ Ejemplo, Michael Parks y William Tuohy (Los Angeles Times), «Para Fortalecer el Socialismo», El Mercurio, Santiago, 4 de noviembre de 1989, p. D3; Alison Mitchell (Newsday), «Vigilia ante la KGB», El Mercurio, Santiago, 4 de noviembre de 1989, p. D3; Jeffrey Sachs (The Washington Post), «Polonia requiere ayuda del Oeste», El Mercurio, Santiago, 10 de noviembre de 1989, p. A10, otros.

24 Mauricio Hoffman, «Libertad, solidaridad y democracia, lo más escuchado en el Congreso de la AFL-CIO», La Segunda, Santiago, 15 de noviembre de 1989, p. 15.

25 «Héroe de la Nación», El Mercurio, Santiago, 30 de noviembre de 1989, p. A3. 
A diferencia de los diarios, las revistas chilenas de temas de actualidad dedicaron artículos al análisis de los acontecimientos europeos, con énfasis en las aristas de los movimientos populares y la demanda de cambios políticos. En esta línea, Hoy recogía: «inédito es el proceso que se está llevando a cabo en Polonia, tras la abrumadora victoria electoral del sindicato Solidaridad en las elecciones del 5 de junio. La oposición ganó todos los escaños parlamentarios a los que podría postular» ${ }^{26}$. El artículo presentó un esbozo de Walesa, haciendo un recorrido desde su comienzo como trabajador en un astillero hasta convertirse en el líder político más importante del país, capaz encabezar las movilizaciones contra la cúpula del régimen comunista.

A medida que la presión ciudadana crecía en los países del Este europeo, también crecía la preocupación de la prensa chilena por el tema y la búsqueda de respuestas a los hechos. Hoy señalaba: «nada de lo que hoy ocurre en Polonia y Hungría sería posible si la URSS no hubiese cambiado tan radicalmente» ${ }^{27}$, refiriéndose de forma clara al liderazgo reformista de Gorbachov, que propició una nueva actitud de la URSS hacia sus aliados del Pacto de Varsovia. Sin embargo, la misma publicación profundizaba en tratar de explicar lo que estaba ocurriendo, al apuntar: «no hay lugar a mucha discusión ideológica cuando, como en Polonia, la comida escasea y el desempleo amenaza ${ }^{28}$. De modo que, tanto los cambios en el discurso soviético hacia sus vecinos como la cruda realidad del sistema comunista, incapaz de alimentar a su propia población, eran parte de las razones que movían a los polacos y húngaros por democracia y libertad.

Desde Austria, el periodista José Siles relató los abruptos episodios de la movilización en masas: «los polacos salen al Oeste porque se mueren de hambre, los rumanos porque no pueden más con su Ubu Rey (Nicolae Ceaucescu), los húngaros para cambiar salchichón por radiocasetes y los otros alemanes para recuperar la patria perdida ${ }^{29}$. El temor y la represión del sistema comunista parecían desvanecerse poco a poco, según la apreciación periodística, que mostraba un relajamiento en la vida cotidiana de los europeos orientales en un atisbo de libertad.

${ }^{26}$ Edith Flores, «Su turno, seños Walesa», Hoy, Santiago, No. 631, del 21 al 27 de agosto de 1989 , p. s.n.

27 Alejandro Magnet, «Los intrincados caminos del Este», Hoy, Santiago, No. 634, del 11 al 17 de septiembre de 1989 , p. s.n.

28 Alejandro Magnet, «Los intrincados caminos del Este», p. s.n.

29 José Siles, «Huida en masa», Hoy, Santiago, No. 635, del 15 al 24 de septiembre de 1989 , p.s.n. 
Asimismo, las impresiones narradas por Hoy reflejaban al mismo tiempo el dramatismo del momento y las posiciones de la revista, al afirmar «la RDA comparte hoy con la Rumania del gran Conductor Ceaucescu el farolillo rojo en el mundo del surrealismo socialista. Berlín-Este y Bucarest no quieren reconocer la evidencia de que, después de 40 años de mentiras y de promesas vacías, la gente sólo espera que el régimen termine de hundirse de una vez» ${ }^{30}$. Las lecturas e interpretaciones apuntaban al fracaso del comunismo como sistema, pero, ante todo, a la búsqueda natural del ser humano de la libertad, que compaginaba con este retrato de acciones ciudadanas espontaneas, sin líderes o partidos políticos a la cabeza.

En este orden, Caras dedicó especial atención a la crisis del comunismo oriental entre fines de 1989 e inicios de 1990. De esta manera, la publicación recogió el ambiente de la época: «desde hace un mes, cientos de miles de checoslovacos, muchos con velas encendidas y cantando «iSvobodu!» («ilibertad!»), han llenado la plaza de San Wenceslao de Praga. Día tras día, estudiantes en jeans, mujeres embarazadas, parejas con guaguas, obreros, todos, han salido a las calles para pedir cambios. Han sido las protestas más multitudinarias en los 71 años de vida de Checoslovaquia» ${ }^{31}$. Las imágenes retratadas por Hoy y Caras coincidieron en destacar el carácter popular y espontaneo de las movilizaciones de los europeos, en este caso los checoslovacos, mostrando un amplio abanico social y generacional, sin distinción de sexo, que demandaban libertades civiles y políticas.

En este contexto, Alemania Oriental y Rumania fueron dos casos excepcionales para la prensa chilena. El primero debido al simbolismo del Muro de Berlín en medio de la Guerra Fría (el cual se desarrollará más adelante), y el segundo por haber sido uno de los últimos países en experimentar la ola de cambios democráticos, pero también por haber sido uno de los más violentos. Uno de los últimos bastiones comunistas de Europa oriental era la Rumania de Ceaucescu. Caras recogió aquellos acontecimientos de fines año,

de la noche a la mañana, el pueblo rumano se rebeló. No fue más esa nación sumisa que el mundo había conocido. Influenciados por los vientos de cambio, millones de rumanos decidieron imitar a sus vecinos de Europa oriental (...) Los Ceausescu no tomaron en serio las pro-

\footnotetext{
30 José Siles, «Huida en masa», p. s.n.

${ }^{31}$ Carolina García-Huidobro, «¡Volvió la primavera!», Caras, Santiago, No. 44, 20 de diciembre de 1989, p. 33.
} 
testas. Creyeron que era cosa de reprimir igual que en China y se equivocaron rotundamente. La paciencia de los rumanos se acabó y ya no hubo quien los controlara ${ }^{32}$.

La crudeza retratada atestiguaba la violencia de las últimas órdenes de Ceausescu por reprimir las protestas, frente a lo que los rumanos respondieron con mayor ímpetu. Al igual que otros procesos similares en la región, el movimiento rumano también revistió la misma espontaneidad que sus vecinos, pero con una intensidad mayor, probablemente por la conjunción de la ausencia de calefacción en invierno y el mismo personalismo de Ceausescu. En otro artículo de Caras, se publicaron las fotografías de la masacre Timisoara ordenada por Ceausescu. Estas fuertes imágenes, que ya de por sí solas eran impactantes, narraron los últimos días de la dictadura comunista. A finales de diciembre, Nicolae y Elena Ceaucescu fueron capturados por las Fuerzas Armadas, juzgados por una corte marcial, y ejecutados. Las imágenes de sus cadáveres fueron transmitidas el 25 de diciembre por la televisión rumana. Sin embargo, Caras relató las crudas escenas de Rumania: «en las calles no hubo tiempo ni ánimo para celebrar. En medio del dolor y de un frío de diez grados bajo cero, los rumanos debieron comenzar a enterrar a los muertos... No había dónde enterrar a tantos, y debieron sepultarlos en los parques de la Libertad, de Cismigiu y el Jardín Botánico» ${ }^{33}$.

Después de 1989, el mundo ya no era el mismo, pero ¿quién tenía las respuestas de lo sucedido? Probablemente nadie en ese momento, ni siquiera el más avezado de los analistas. No obstante, nuevamente las revistas chilenas trataron de buscar explicaciones de lo ocurrido en Europa oriental frente a lo abrumador de los acontecimientos. En febrero de 1990, Caras procuró brindar un análisis más reposado de los hechos europeos con un balance general de los movimientos democráticos, al señalar «ante el asombro del mundo entero, uno a uno fueron cayendo los ortodoxos regímenes comunistas de Europa Oriental que por más de 45 años habían mandado en esos países. La nueva década partió prometiendo democracia y elecciones libre» ${ }^{34}$.

32 Carolina García-Huidobro, «El dolor de Rumania», Caras, Santiago, No. 45, 3 de enero de 1990, p. 53.

33 Carolina García-Huidobro, «Imágenes de la masacre» (Rumania), Caras, Santiago, No. 47, 31 de enero de 1990, p. 35.

34 «Operación Descuelgue. Comunismo en Europa Oriental», Caras, Santiago, No. 48, 14 de febrero de 1990 , p. 58. 
En contraste, los medios izquierdistas optaron por contraponer lo ideológico a los hechos. Primero, al guardar silencio sobre lo ocurrido en Europa oriental ${ }^{35}$; y, luego, al disminuir la dimensión de los acontecimientos europeos o procurando transformar los movimientos por la democracia en parte de las reformas soviéticas. El Siglo, órgano oficial del PC chileno, acabo de ser relegalizado en septiembre de 1989. Su postura era de izquierda ortodoxa, menos abierta a los cambios, esto en relación con otros medios de izquierda, como Pluma y Pincel, que era más crítica con los problemas que enfrentaba el comunismo internacional. Por ejemplo, sobre los acontecimientos en Polonia, El Siglo sentenció: «Estados Unidos y la URSS han reaccionado con cautela ante el nuevo rumbo polaco, aunque por diferentes motivos. Washington está a la espera de conocer medidas concretas para recabar el apoyo de gobiernos aliados e incrementar su prometida ayuda económica de 119 millones de dólares a Varsovia» ${ }^{36}$. Para el órgano del PC, lo ocurrido en Polonia se debía mucho más al dinero «prometido» por Estados Unidos que a las demandas y movilizaciones populares de los polacos. Es decir, se intentaba mostrar que los hechos acaecidos provenían de un agente externo, no del interior del sistema.

En una entrevista a Camilo Contreras, secretario de las Juventudes Comunistas chilenas, se le consultó sobre la masiva emigración de ciudadanos de la RDA, a lo que contestó: «Hay un afán de acentuar todas estas cosas, porque esto tiene efectos en los estados de ánimo, en la creación de imágenes. Ahora ¿a que se va esa gente a la RFA? ¿a resolver su educación, la cesantía?, ¿acaso no hay cesantía en la RFA? Pero yo creo que el Partido Socialista Unificado Alemán está preparado para esta embestida» ${ }^{37}$. La postura de Contreras era radical y dogmática, no concebía la posibilidad de demandas de libertad de los alemanes-orientales ni reconocía la exigencia de fondo al régimen comunista, la represión al individuo. Por el contrario, el secretario de las JJ.CC. PC defendía fervientemente al «Partido Socialista» alemán, que dejaba ver la posición ortodoxa del diario.

35 De hecho, en los números de Pluma y Pincel de agosto a octubre de 1989 no aparecieron artículos sobre el proceso de cambio político en Europa oriental.

36 «Histórico paso de Polonia genera esperanzas y dudas», El Siglo, Santiago, 17 de Septiembre de 1989, p. s.n.

37 Juan Carrera, «He aprendido a vivir con un justo control sobre la sensibilidad», El Siglo, Santiago, del 18 de Septiembre al 1 de Octubre de 1989, p. 8. 
Ante las innegables movilizaciones ciudadanas en Europa oriental en contra de los regímenes comunistas, El Siglo afirmaba sobre la crisis del sistema: «estamos viviendo un período de grandes reajustes. Pero no ha sido derrotado el socialismo. En vísperas del próximo milenio vuelve a sus cauces verdaderos y, a pesar de los desbordes es indiscutible que seguirá su curso y demostrará que es una forma superior de organización de la sociedad ${ }^{38}$. Resulta evidente que, para El Siglo, las críticas y exigencias al socialismo eran sencillamente un «reajuste», y se defendía a ultranza la supervivencia del modelo comunista. Esta posición refleja la distancia entre la construcción teórica de la ideología y la realidad de las demandas y necesidades humanas de sus ciudadanos. Parecía haber un abismo entre lo que mostraba el periódico y lo que reclamaban las personas en las calles de Europa.

Por su parte, Pluma y Pincel ${ }^{39}$ sostenía: «el socialismo no ha muerto como quieren algunos. La democratización del sistema impone un desafío al futuro ${ }^{40}$. La publicación recogió un conjunto de entrevistas a varios dirigentes políticos comunistas y socialistas, chilenos y algunos extranjeros, como a José Visiani, del PC chileno, quien afirmaba sobre los cambios en Europa oriental que «en países como Chile, es manipulado por la gran prensa y presentado como «el fin del comunismo y el socialismo» ${ }^{41}$. Así, quedaba claro que, para una parte de la izquierda chilena, lo que se conocía en el país sobre ocurrido en Europa oriental era producto de cómo lo presentaban los medios de comunicación, no del sistema ni sus fallas.

Igualmente, dicha revista reprodujo un discurso de Fidel Castro sobre la crisis del socialismo. Castro recriminó los cambios hacia el capitalismo, señalando: «el imperialismo hoy invita a los países socialistas de Europa a convertirse en receptores de sus excedentes de capital, desarrollar el capitalismo y participar en el saqueo de los países del Tercer Mundo» ${ }^{42}$. La publicación parecía indicar que la revista se aferraba a la posición más ortodoxa de disminuir las demandas de los europeos orientales por cambios democráticos en sus países.

38 Simón Blanco, «¿Está en crisis el socialismo?», El Siglo, Santiago, del 13 al 26 de noviembre de 1989 , p. 3 .

39 Pluma y Pincel comenzó su tercera etapa en 1988, cuando volvió a circular como un medio alternativo de izquierda, dirigido por Leonardo Cáceres y José Varas.

40 José Córdova, «Ojo a la Perestroika», Pluma y Pincel, Santiago, No. 99, 02 de noviembre de 1989, p. 26.

41 José Córdova, «Ojo a la Perestroika», p. 26.

42 «La experiencia cubana y la crisis del socialismo», Pluma y Pincel, Santiago, No. 107, 28 de diciembre de 1989, p. 17. 
Hacia fines de 1989, José Varas, periodista de Pluma y Pincel, viajó a Rumania y desde allí relató lo que pudo ver sobre el proceso rumano. Varas narró dos caras del país. En una, los vítores y coreografías de culto a la personalidad del «héroe»; en otras muy distinta, la del frío por racionamiento de energía y la escasez de alimentos. Así, en palabras del periodista, en el XIV Congreso del PC rumano, «cada vez que la voz áspera y cascada del líder finalizaba un pasaje con ciertas inflexiones particularmente enfáticas, los tres mil 300 delegados se ponían de pie de un salto, con entusiasmo instantáneo y unánime.» Al mismo tiempo, señala: «las tiendas de comestibles son un desierto ${ }^{43}$. Este artículo revestía una doble significancia, ya que, por un lado, se evidencia la importancia de los movimientos en Europa oriental con el envío de un periodista a Rumania; $\mathrm{y}$, por el otro, se comenzaba a reconocer, aunque tenuemente, la realidad de los problemas del sistema comunista en cuanto a las desigualdades sociales, el desabastecimiento de alimentos y de energía para calefacción, lo que ya se hacía innegable, incluso para un medio como este.

Por otra parte, el editorial de La Época, del 16 de diciembre de 1989, recogió los avatares de aquel año para el continente europeo al sostener «el complicado clima europeo fue reflejado alegremente en sus medios de comunicación social», con lo que atestiguaba el ánimo con el que fueron plasmados los cambios del viejo continente. Más adelante, el mismo texto apuntaba también las nuevas transformaciones del país: «Chile, saliendo de las sombras, retoma sus ejemplares tradiciones democráticas, hoy evocadas en todos los rincones de la tierra y se reimplanta en el escenario del mundo, del que estaba penosamente alejado. Y lo hace en perfecta sintonía con las tendencias vigorosas de una comunidad internacional en plena renovación ${ }^{44}$.

En sus páginas, La Época se sumaba a la percepción de vincular los cambios europeos con los cambios en Chile, en el sentido de identificar transiciones a la democracia desde formas autoritarias. Al mismo tiempo, el diario se hacía eco de otra noción: la salida de Chile del aislamiento internacional y su incorporación plena al escenario global de la mano de una democracia. Sin lugar a duda, La Época refleja las expectativas de un tipo de prensa joven (fundado en marzo de 1987), como una clara voz

43 José Varas, «Rumania: sangriento final de una pesadilla», Pluma y Pincel, Santiago, No. 107, 28 de diciembre de 1989, p. 27.

44 «Chile, el mundo y el retorno a la democracia» (Editorial), La Época, Santiago, 16 de diciembre de 1989 , primera página. 
opositora al gobierno militar y auspiciadora del plebiscito de 1988, lo que explica su posición al comparar los sistemas en Chile y Europa del Este.

En suma, muchos de los medios chilenos se mantuvieron expectantes sobre los acontecimientos en Europa oriental, guardando cierto optimismo por el derrumbe del sistema comunista, porque se apreciaba un símil con el proceso de transición a la democracia que experimentaba el país. No obstante, parte de la prensa izquierdista parecía apresurarse a disminuir los hechos, culpar a los medios «occidentales» u ocultarlos bajo el argumento de que formaban parte de las reformas soviéticas. En todo caso, la atención de la mirada chilena permaneció enfocada en los sucesos europeos orientales, en una combinación de incredulidad, optimismo y asombro.

\section{Muro de Berlín: simbolismo y coyuntura}

Pocas veces murallas de concreto han alcanzado tal atención de la historia como el Muro de Berlín. Aquel muro, triste y celebre a la vez, de gris cemento y tatuado de grafitis, no sólo se convirtió en uno de los mayores símbolos de la Guerra Fría, sino también del extremismo ideológico comunista y de la lucha por la libertad humana ${ }^{45}$. Por ello, no resulta sorprendente que los medios chilenos se volcaran a cubrir la noticia del momento, la caída del muro berlinés, que eclipsó la cobertura mediática, los análisis y opiniones de la prensa chilena en distintas expresiones.

Las columnas de opinión de El Mercurio fueron un importante escenario de las repercusiones de la caída del Muro de Berlín en la prensa chilena. En sus páginas aparecieron artículos, como el de Enrique Barrios, que señalaba, dentro del contexto de los movimientos ciudadanos, que en Europa del Este se valoraba la democracia, precisamente, porque permitía la posibilidad de cambios políticos, y apuntaba: «muchos intelectuales persisten en su juicio lapidario sobre el materialismo y vulgaridad de las sociedades capitalistas y democráticas. Pero saben que allí siempre habrá algún espacio legitimo para las ideas humanistas» ${ }^{46}$. Asimismo, el diario trasmitía claramente su posición frente a los recientes acontecimientos en Europa oriental, al decir que «el fenómeno más notable que está obser-

45 Sobre el Muro berlinés, véase: Garzón, 2013; Major, 2010; Die Todesopfer an der Berliner Mauer 1961-1989, 2009; Hertle, 2007.

46 Enrique Barros, «Berliner Alexander-Platz», El Mercurio, Santiago, 7 de noviembre de 1989 , p. A3. 
vando la opinión pública mundial es, pues, que los propios partidos comunistas de la órbita soviética han decidido relegar al cuarto de los trastos viejos las absurdas elaboraciones marxistas-leninistas, que tanta sangre, dolor y frustración han llevado a media humanidad» ${ }^{47}$. Sin lugar a duda, desde El Mercurio se observaba el bloque comunista como un resabio anticuado de la Guerra Fría, que había mostrado su fuerte impacto sobre su propia población.

En esta línea, se inserta el artículo de José Navasal, quien se preguntaba sobre el panorama de Europa, Alemania y el comunismo, al sostener que «Europa debe mirar con suma cautela el movimiento democrático en la república alemana del Este. Pero el Viejo Mundo debe tomar en cuenta que los que repudian el comunismo traen consigo también el posible germen de un nuevo conflicto» ${ }^{48}$. El autor mostraba sus preocupaciones por el futuro inmediato de los movimientos europeos, ¿qué vendría después? Algo que nadie sabría o podría prever, por lo que el autor se cuestionaba sobre una posible Alemania unificada, lo que denotaba las inquietudes en el ambiente intelectual chileno.

Por su parte, La Tercera dedicó un editorial a la caída del muro berlinés, en el que calificaba al muro como «la fatídica barrera», al tiempo que observaba que el derrumbe «constituye quizás la democratización más clara de la crisis terminal del comunismo» ${ }^{49}$. Más adelante, el mismo editorial afirmaba: «Los dogmas del comunismo fueron poco a poco cediendo terreno ante los irrefutables avances de una economía de mercado que, unida a la democracia, aparece como la respuesta válida a los acusantes problemas que enfrenta la Humanidad cuando se apresta a ingresar al Siglo XXI» ${ }^{50}$. El periódico santiaguino expresó su optimismo - y júbilo- por el derrumbe del muro berlinés y la crisis del sistema comunista: era notorio el argumento del diario por el hastió del «dogma» comunista frente a los avances materiales de la economía de libre mercado en una democracia, las diferencias no podían ser más disimiles entre la Alemania occidental, prospera y pujante, y la Alemania oriental, empobrecida y deprimida económicamente.

47 «Derrumbe inevitable», El Mercurio, Santiago, 11 de noviembre de 1989, p. A3.

48 José Navasal, «¿Una sola Alemania?», El Mercurio, Santiago, 11 de noviembre de 1989, p. D3.

49 «Adiós al Muro de Berlín»(Editorial), La Tercera, Santiago, 12 de noviembre de 1989 , p. 3 .

50 «Adiós al Muro de Berlín»..., p. 3. 
De igual manera, en la sección «Tribuna del Lector», La Tercera recogió las impresiones, en la calle, de seis chilenos diferentes, hombres y mujeres, jóvenes y adultos, tanto del norte como del sur del país, sobre el «histórico» Muro. Al respecto, el diario sentenció: «un contundente apoyo recibió la apertura del denominado «Muro de Berlín», por parte de los chilenos encuestado [...], quienes reconocieron en este hecho un avance en favor de la paz mundial» ${ }^{51}$. La consulta popular de La Tercera resultó única entre los medios chilenos, y permitió mostrar otra mirada de la noticia en pleno desarrollo: la opinión de los ciudadanos, en la que todos los consultados expresaron asombro y optimismo por la caída del muro.

La mirada de los hechos desde otro ángulo llevó también a los medios chilenos a consultar otros testimonios. Una de las primeras impresiones sobre los acontecimientos en Alemania Oriental y la apertura del muro fue recogida en Santiago, de voz de un alto diplomático. En una entrevista, Hans Ulrich Spohn, consejero de la Embajada alemana-occidental en Chile, mostró su satisfacción por el proceso que se estaba viviendo en Berlín, y expresó: «me parece muy difícil retornar al estado estalinista. Es imposible establecer otra vez una dictadura militar, faltan las condiciones, falta el pretexto, falta la fe en le ideología [sic] y un clima general que favorezca una medida de ese tipo. Tienen que dar respuesta al grito de la gente de allá y eso quedó muy claro en la RDA» ${ }^{52}$.

La importancia de los acontecimientos en Berlín llevó a La Segunda a enviar un equipo reporteril a Berlín. Así, en los días siguientes a la apertura del muro, el periódico entregó reportajes día a día de los principales hechos. La enviada especial recogió: «es fácil constatar, al recorrer esta hermosa ciudad que está más brumosa y fría, el interés con que se siguen los discursos pronunciados por los líderes orientales» ${ }^{53}$. Más tarde, la periodista agregó:

el muro, que desde hoy también se ha permitido cruzarlo en bicicleta y motos, es una fijación monotemática y, para algunos también impenetrable. $[\ldots]$ Con efusiva amabilidad un «vopos», como les dicen tam-

51 «Contundente apoyo a apertura del histórico «Muro de Berlín», La Tercera, Santiago, 12 de noviembre de 1989.

52 Mariluz Contardo, «Representante alemán en Chile: «Aunque el muro de Berlín ya tenía "agujeros", es emocionante verlo caer», La Segunda, Santiago, 10 de noviembre de 1989, p. 23.

53 María Álamos, «Berlín, después del carnaval», La Segunda, Santiago, 14 de noviembre de 1989 , p. 4. 
bién a los llamados policías del pueblo, nos explicó que con pasaporte los extranjeros podrían hacerlo, pero a pie. El berlinés tenía que ingresar por otro lugar pidiendo su visa correspondiente ${ }^{54}$.

Las impresiones ofrecen un retrato casi pormenorizado de la capital alemana-oriental, en medio de la zozobra y el entusiasmo que recorría las calles. La imagen de La Segunda era inigualable, porque permitían acercarse a la vida cotidiana berlinesa, de los días posteriores del anunció de apertura del muro, vista con ojos chilenos y en plena expectativa por lo que podría suceder después, el día de mañana y el subsiguiente. En aquellos momentos todo parecía incertidumbre en la ciudad alemana, tal como lo relató la enviada especial: «las interrogantes siguen siendo interminables y las mismas tal vez en un lado y en el otro de Berlín. Pero hay esperanzas y se palpa - con emoción - la alegría incontenible de los berlineses. Gestos se ven por aquí y por allá, entre las autoridades y la ciudadanía» ${ }^{55}$.

Las narraciones de La Segunda se convirtieron en publicaciones diarias, enviadas directamente desde el lugar de los acontecimientos, y que reflejaban la singularidad de lo que se estaba viviendo en Berlín, la atmósfera que se respiraba desde el terreno mismo, y vivencias de ciudadanos de pie. Por ejemplo, la corresponsal chilena relató:

produce un estremecimiento permanente ver y caminar entre esa muchedumbre que conversa en voz baja, que va - casi siempre- sujetando varios niños o cargándolos en las espaldas, y que lleva pequeñas bolsas de plátanos, naranjas o chocolates, productos que en su país [Alemania Oriental] les son inalcanzables y que ahora compran con esos 100 marcos que - desde el viernes - regala el gobierno federal a cada visitante mayor de 18 años ${ }^{56}$.

Incluso, el equipo chileno tuvo acceso a la máxima autoridad de Alemania occidental, el presidente de la RFA, Richard von Weizsächer, quien se mostró calmado y desestimó cualquier acuerdo de la OTAN ante

${ }^{54}$ María Álamos, «Berlín, después del carnaval», La Segunda, Santiago, 14 de noviembre de 1989, p. 4.

55 María Álamos, «Vigilia ante la puerta de Brandeburgo», La Segunda, Santiago, 15 de noviembre de 1989 , p. 5.

${ }^{56}$ María Álamos, «Berlín, bajo la luna llena y los reflectores, semeja el escenario de una fantástica y dramática obra teatral», La Segunda, Santiago, 13 de noviembre de 1989, p. 4. 
los acontecimientos suscitados en Berlín ${ }^{57}$. No obstante, en otro artículo se plasmó la frustración de la prensa por superar «otro muro insuperable», «tal vez ahora más impenetrable»: el obtener declaraciones de los comandantes de las fuerzas aliadas o representantes de la Iglesia, «que también tienen mucho que decir» ${ }^{58}$. El silencio de la dirigencia política no hacía más que acrecentar la incertidumbre mundial y el desasosiego de la gente en la calle. En otro reportaje, La Segunda recogió una entrevista a una exespía de la RDA. En ella, la mujer, de 36 años y con una hija, expresó:

Es la ideología y todo el sistema lo que ahoga a las personas. Todos sentimos miedo de tener algún problema con la policía.

Yo trabajaba dentro de la embajada de Suiza y estaba obligada cada mes a contar todo lo que pasaba adentro. Una vez al mes me hacían interrogatorio.

Yo era una espía ${ }^{59}$.

La dramática situación de aquella mujer correspondía, en parte, a la vida cotidiana de la gente común, la que desbordaba por miles el Berlín occidental. En su conjunto, los reportajes de La Segunda fueron únicos, porque constituyeron uno de los retratos más amplios y más completos del abanico social de Berlín, visto y narrado desde los distintos enfoques de quienes vivieron los acontecimientos, lo que convirtió cada entrega del diario en un testimonio revelador de la magnitud de los hechos y de las repercusiones en esos berlineses anónimos que aspiraban a vivir en libertad y democracia.

Del mismo modo, las revistas chilenas se hicieron eco de la caída del muro a través de varios artículos relacionados con Berlín y las dos Alemanias. La noticia era prácticamente la sensación del momento, recibía todas las atenciones y los periodistas se apresuraban en tratar de recoger las piezas del rompecabezas: ¿cómo?, ¿quienes?, ¿por qué?, entre otras, eran las principales inquietudes que las publicaciones intentaban responder. Justo una semana después de la apertura oficial del muro berlinés, Caras dedicó sus esfuerzos a retratar aquellos días: «ya no hay nada que les im-

57 María Álamos, «Richard von Weizsacher: La policía militar de Berlín Oriental ha venido al límite con Occidente cargada de armas. Y al ver lo que han visto, las han abandonado», La Segunda, Santiago, 13 de noviembre de 1989, p. 5.

58 María Álamos, «Álgidos debates en el Parlamento, mientras la puerta de Brandeburgo aún no se abre», La Segunda, Santiago, 16 de noviembre de 1989, p. 5.

59 María Álamos, «Yo era una espía...», La Segunda, Santiago, 17 de noviembre de 1989, p. 18. 
pida ir de un lado al otro. Incluso, Moscú ha insinuado que no le importaría que eligieran un gobierno no comunista en Alemania del Este, siempre y cuando siguieran siendo sus aliados en el Pacto de Varsovia. Pero si esta Alemania dejara de ser comunista, ¿por qué continuar teniendo dos Alemanias? $\gg^{60}$. La efusión de esos instantes por el término del muro, y lo que éste representaba, dio paso a un choque con la realidad, generando el temor ante una posible invasión armada de la URSS, o la interrogante más optimista en ese entonces ¿podrían unificarse las Alemanias del Este y Oeste? Probablemente, muy pocos lo sabían, pero estaba comenzando a estar el ambiente la idea de una posible unificación.

En este mismo tono, la publicación santiaguina retomó el tema y las preocupaciones por el qué pasará ahora, al tiempo que surgía la reflexión en torno al muro como una herida abierta no sólo de los alemanes, sino también del mundo entero ante el hecho de cómo explicar la división y la opresión. Al respecto, Caras recogió: «fue un momento único. Porque esa «muralla de la vergüenza» que por más de 28 años permaneció allí como el símbolo más patético de la división de Europa y el del mundo en dos bloques irreconciliables, la noche del 9 de noviembre se convirtió en un desbordante lugar de alegría y reencuentro. Hermanos, padres, hijos y amigos pudieron volver a verse después de muchos años» ${ }^{61}$. Sin lugar a duda, el 'muro de la vergüenza', como fue llamado en la prensa occidental, era mucho más que el símbolo de la división material de la ciudad de Berlín; representaba la separación del mundo en dos visiones antagónicas entre sí, por esta razón la prensa chilena mostró su optimismo por un espacio de entendimiento futuro a partir de las muestras de efusión entre los berlineses.

El Siglo y Pluma y Pincel, ambas de orientación izquierdista, tenían una percepción distinta sobre la caída del Muro de Berlín. Para El Siglo, el cruce masivo del Muro de Berlín por los berlineses orientales se trataba de algo temporal, y que, en cambio, mostraba el desdén del lado oeste por los nuevos visitantes. El periódico sostenía que «Berlín Occidental cambió bruscamente su rostro. Deambula por sus calles una población flotante que está incubando serios problemas, según un periodista de la llamada ciudad Vitrina. En las grandes tiendas se ven ahora policías privados, que antes no existían o no se advertían. Todos los días una corriente humana

60 «Cayo el Muro», Caras, Santiago, No. 41, 15 de noviembre de 1989, p. 105.

${ }^{61}$ Carolina García-Huidobro, «Después de las lágrimas», Caras, Santiago, No. 42, 29 de noviembre de 1989, p. 35. 
permanente cruza la frontera «¿Cuánto durara el deslumbramiento?», se pregunta mi colega y sonríe» ${ }^{62}$. El hecho era innegable, los alemanes orientales habían pasado el muro hacia el oeste, y comenzaban a descubrir un abanico de opciones de la economía capitalista, pero El Siglo retrataba esto con recelo y desestima, especialmente hacia los berlineses del oeste.

De igual forma, Pluma y Pincel consideró que los sucesos en torno al muro berlinés habían sido presentados con «confusiones y exageraciones» por los medios de comunicación. De esta forma, en una sola hoja, la revista señaló: «las agencias periodísticas internacionales, siempre a la búsqueda de un sensacionalismo competitivo, lanzaron tal cantidad de dislocadas elucubraciones que fue muy difícil formarse un panorama claro de lo que realmente estaba sucediendo en Berlín ${ }^{63}$. A lo que agregaba sus cuestionamientos sobre la cantidad de personas que cruzaron hacia Berlín oeste, que según la revista, alrededor de 15.000 berlineses del este habían atravesado el muro y sólo 5.000 se habían quedado del lado occidental.

Las páginas de Pluma y Pincel alabaron la labor del premier soviético Mijaíl Gorbachov por la renovación y búsqueda de un término de la Guerra Fría, en función de su actuación en la Cumbre de Malta, del 3 y 4 de diciembre; y la condena que hicieron los parlamentos de Polonia y Hungría a la invasión militar perpetradas por los miembros del Pacto de Varsovia a Checoslovaquia en agosto de $1968^{64}$.

En una entrevista, a propósito de los sucesos de Berlín, Guaraní Pereda, del Comité Central del Partido Socialista de Chile y exiliado diez años en la RDA, declaró que el Partido Socialista Unificado de Alemania (PSUA) había sufrido «un verdadero terremoto social, de desprestigio del Partido ante las masas populares» ${ }^{65}$, y que estaba en marcha un cambio «irreversible». Sin embargo, el propio Pereda agregaba dentro de la PSUA, «los liderazgos de estos movimientos opositores siguen sosteniendo la idea del socialismo y de la RDA, como Estado socialista, con perfiles propios».

62 Jorge Soza, «Berlín al partir», El Siglo, Santiago, del 25 de diciembre de 1989 al 7 de enero de 1990, p. 14.

${ }^{63}$ Loreto Herrera, «Cae el muro de la ira. (Y la Perestroika llego a Berlín)», Pluma y Pincel, Santiago, No. 101, 16 de noviembre de 1989, p. 30.

64 J.M.V., «Los vertiginosos sucesos europeos», Pluma y Pincel, Santiago, No. 104, 07 de diciembre de 1989, pp. 30-31.

65 José Varas, «Inventar un nuevo socialismo», Pluma y Pincel, Santiago, No. 105, 15 de diciembre de 1989, pp. 27-29. 
En sintonía con su línea editorial, Pluma y Pincel reprodujo una carta de la escritora alemana oriental Helga Konigsdorf, que la revista calificó como «un testimonio, doloroso y relevador, representativo de la posición y los sentimientos de los que en medio de la crisis que sacude a la República Democrática Alemana, siguen creyendo y luchando por el socialismo» ${ }^{66}$. La escritora y militante, nacida en 1938, hacía un recuento de sus lealtades al partido y sus ideas. Entre sus líneas afirmaba: «permanezco en el Partido también por los muchos que simplemente han creído y para los que se ha roto su mundo». Quedaba claro que en el torbellino de los acontecimientos no sólo había caído el muro, sino también un sistema y el entramado que sostenía aquel régimen, lo que despertó la euforia en los jóvenes que se acercaron al muro, pero también la nostalgia de los militantes políticos que veían venirse abajo sus creencias en el sistema.

En definitiva, Alemania y el Muro de Berlín constituyeron el objetivo de principal atención de la prensa chilena, por sobre los otros movimientos de Europa oriental. En parte, esto pude explicarse por el simbolismo que representó el muro en el imaginario colectivo, como sinónimo de división material e ideológica del mundo entre dos visiones contrapuestas. Especialmente, en Chile, Alemania como nación y la cultura germana como expresión han sido motivo de admiración constante por parte de la elite militar y científica desde fines del siglo XIX, por lo que los acontecimientos en aquella tierra lejana obtuvieron una preocupación extra, además del aliciente de la presencia de inmigrantes alemanes y sus descendientes en el sur chileno ${ }^{67}$.

\section{Más allá del Muro: otras visiones chilenas}

La caída del Muro de Berlín sobrepasó el ámbito informativo de la prensa chilena, para convertirse en uno de los más relevantes temas de discusión y opinión. A través de la tinta y el papel de los medios, los caricaturistas, columnistas y políticos se sintieron inspirados o comprometidos para expresar sus diversas percepciones sobre el acontecimiento mundial del momento. Es más, en medio de la campaña electoral chilena de

${ }^{66}$ Loreto Herrera, «Por qué permanezco en el Partido», Pluma y Pincel, Santiago, No. 106, 21 de diciembre de 1989.pp. 26-27.

67 Véase: Brahm, 2002; Brahm, 2015; Krebs, 2001; Muñoz, 2008, pp. 23-51, otros. 
1989, como telón de fondo, resultó un tema importante en el plano ideológico.

La cuestión era clara, el derrumbe del comunismo en Europa oriental, y el consiguiente proceso de democratización de la región, representaban una situación de incertidumbre y temor por lo que podría ocurrir a nivel regional y nacional ¿cuál sería el proceder de la jefatura local del PC y la figura de Castro en América Latina? En un artículo, el columnista Eduardo von Klausen, de La Nación, confirió duras críticas hacia la actitud de los dirigentes comunistas y socialistas de Chile y Cuba. Klausen apuntó: «entre los que se encuentran más desorientados están el dictador cubano Fidel Castro - quien ha expresado que se opondrá a cualquier tipo de innovación política o socioeconómica - y los jerarcas chilenos de la ex UP y que hoy encabezan al Partido Comunista y socialista criollo, es decir, Volodia Teitelboim, Luis Corvalán, y Clodomiro Almeyda» ${ }^{68}$. Desde su ángulo, el columnista Rafael Valdivieso Ariztía, de La Segunda, señalaba: «es que el comunismo, aunque dé la apariencia de ablandarse y renovarse, no puede abjurar de sus dogmas, entre los cuales está precisamente el empleo de la violencia y el recurso a la dictadura para imponer y proteger esos principios ${ }^{69}$. Por su parte, Juan de Dios Carmona, exministro de Defensa, escribió:

Nótese que todo ha ocurrido desde el interior de los pueblos. Son los mismos pueblos que los comunistas suponían sometidos e ideologizados para siempre, los que han unido voces, para gritar por su liberación de un camino que, según sus propias expresiones, «los conducía a ninguna parte». No ha sido la presión ni la propaganda de Occidente la que ha producido el estallido. Por lo demás, los líderes de este no lo comprenden y no saben qué hacer en estos momentos, tal vez porque temen que la barrera que también definía «lo occidental» caiga a la vez para dar paso a un hombre más completo, más libre, más espiritual ${ }^{70}$

Para Carmona, el proceso fundamental de la caída del comunismo en Europa provenía de las mismas movilizaciones ciudadanas, era la

68 Eduardo von Klausen, «La Desorientación de los Jerarcas Marxistas», La Nación, Santiago, 11 de noviembre de 1989, p. 8.

69 Rafael Valdivieso, «A caballo sobre el muro», La Segunda, Santiago, 14 de noviembre de 1989 , p. 8.

70 Juan Carmona, «Reflexiones sobre el Muro», La Nación, Santiago, 14 de noviembre de 1989, p. 6. 
gente que había nacido y vivido en el propio sistema la que demandaba libertades. Su opinión subraya la ausencia de la intervención occidental, al tiempo que cuestiona si verdaderamente en Occidente se ha producido una reflexión sobre lo ocurrido y su alcance en la naturaleza humana.

Por su parte, el dirigente político Gutenberg Martínez, del Partido Demócrata Cristiano (DC), compartió su beneplácito por los sucesos de Berlín, y sostenía «las dictaduras y los autoritarismos, sean de extrema derecha o de extrema izquierda, van experimentando un retroceso que enaltece la civilización mundial», y más tarde añadió «los avances democratizadores en Polonia se realizan en paralelo a los de Chile, y los de Hungría con los de Paraguay». Sin embargo, pese al marcado optimismo del político democristiano, también era realista y advertía que «aún existen islas importantes, Sudáfrica y Cuba son ejemplos de países en que las concepciones antidemocráticas se mantienen ${ }^{71}$. La opinión de Martínez resulta valiosa no sólo por la dimensión global y comparativa que abarca, sino también porque provenía de una de las voces más representativas de la coalición política de la Concertación, opositora al gobierno militar y propulsora del retorno a la democracia.

Por otra parte, el dirigente conservador Jaime Guzmán, fundador de la Unión Demócrata Independiente (UDI), también se pronunció sobre lo acaecido en suelo berlinés. Al respecto, Guzmán sostuvo: «el fin de semana pasado el corazón de todos los hombres y mujeres libres del mundo se estremeció de júbilo. Confieso que mi alegría se mezcló con esa emoción que anuda la garganta. Había caído el Muro de Berlín (...) celebramos así la mayor victoria de nuestros ideales en este siglo» ${ }^{72}$. Para Guzmán, el hecho representaba un sentimiento personal y un símbolo político de su tiempo.

Curiosamente, en medio de la campaña electoral de 1989, el tema de la caída del Muro fue escasamente comentado por los dos principales candidatos presidenciales, Hernán Büchi, por los partidos UDI y Renovación Nacional (RN), y Patricio Aylwin, por la Concertación. De hecho, solo Büchi se pronunció sobre el asunto, durante su visita a La Ligua, La Calera y Quilpué, al referir: «tenemos que ser capaces de derribar nuestro propio «muro de Berlín», derribar las ideas que han mantenido separado a Chile entre familias que piensan distinto ${ }^{73}$. El tono del discurso

71 Gutenberg Martínez, «Los triunfos de la libertad», La Segunda, Santiago, 14 de noviembre de 1989, p. 12.

72 Jaime Guzmán, «Júbilo y desprecio», La Tercera, Santiago, 19 de noviembre de 1989.

73 «Tenemos que derribar en Chile nuestro propio muro de Berlín», La Nación, Santiago, 11 de noviembre de 1989, p. 11. 
era conciliador y equilibrado, mostrando la necesidad de reunir nuevamente a los chilenos, tras de la polarización existente desde 1973. Por otro lado, Aylwin evitó mencionar la caída del muro, es más, ni siquiera lo mencionó en sus memorias sobre esta etapa ${ }^{74}$. Sin que haya habido una explicación oficial, resulta plausible que su silencio se haya debido a la circunstancia electoral del momento, en el que su coalación política, la Concertación, estaba integrada también por el partido Comunista chileno, para el cual todo asunto relacionado con el Muro de Berlín y el colapso del comunismo en Europa era - en el menor de los casos- espinoso ${ }^{75}$.

Otra mirada provino de El Mercurio, que publicó un artículo del novelista cubano Guillermo Cabrera Infante, en el que reflexionaba sobre la situación del momento y la ideología que los había llevado allí. Cabrera sostenía que «para nosotros, los cubanos, el socialismo fue una broma pesada que nos gastaron, que nos gastan todavía», con lo que reflejaba la incertidumbre respecto a que los cambios vividos en Europa oriental tuviesen algún análogo en la isla caribeña. Al mismo tiempo, el escritor trataba de contemplar la dimensión del problema, al considerar que «el socialismo no es más que una utopía destinada siempre a convertirse en distopía, que es el paraíso del diablo. Ahora hemos visto que paraísos utópicos como Hungría y Polonia, países católicos, deciden que el reino de este mundo no puede ser utópico» ${ }^{76}$, con lo que procuraba observar un mundo más optimista que dejara atrás los regímenes totalitarios.

La Segunda y La Tercera fueron más allá de la cobertura informativa, recogieron reportajes especiales y caricaturas sobre los cambios europeos. Parte de ese trabajo gráfico mostraba los «agujeros» de una manguera que trataba de cercar el PC de la RDA, con Egon Krenz a la cabeza, para contener el flujo reprimido en su interior (Imagen No. 1). Otra caricatura expuso el Muro de Berlín como un símbolo de «opresión», sobre el cual comenzaban a caminar esperanzados los alemanes (Imagen No. 2). Finalmente, en otro dibujo aparecía la figura de un perro, con la cara feliz en Alemania occidental, y a punto de saborear un hueso, a la vez que la mitad de su cuerpo se hallaba al otro lado del muro (Imagen No. 3); no deja de ser significativo el acto del canino con su pata levantada.

74 Aylwin, 2018.

75 Sobre PC chileno, ver Riquelme, 2009.

76 Guillermo Cabrera Infante, «¿Ha muerto el socialismo?», El Mercurio, Santiago, 30 de noviembre de 1989 , p. A2. 


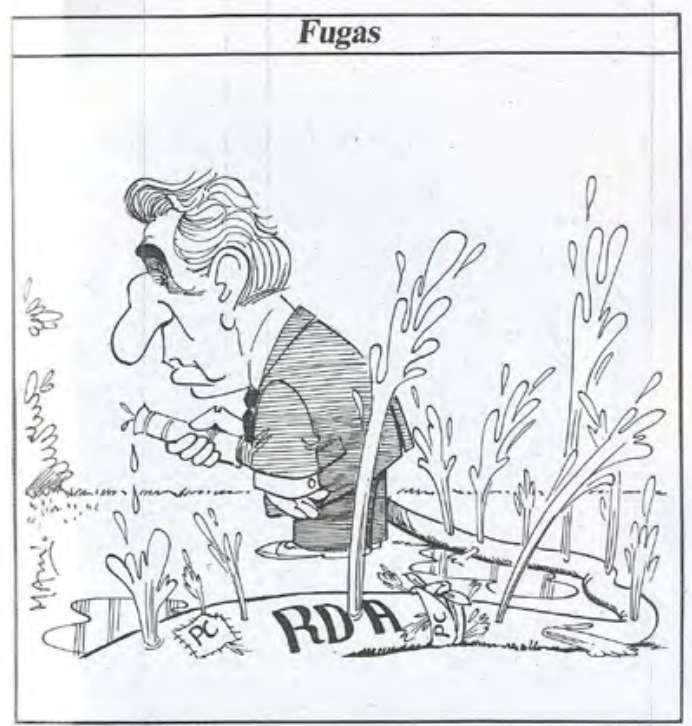

Imagen 1

La Segunda, 9 de noviembre de 1989, p. 7

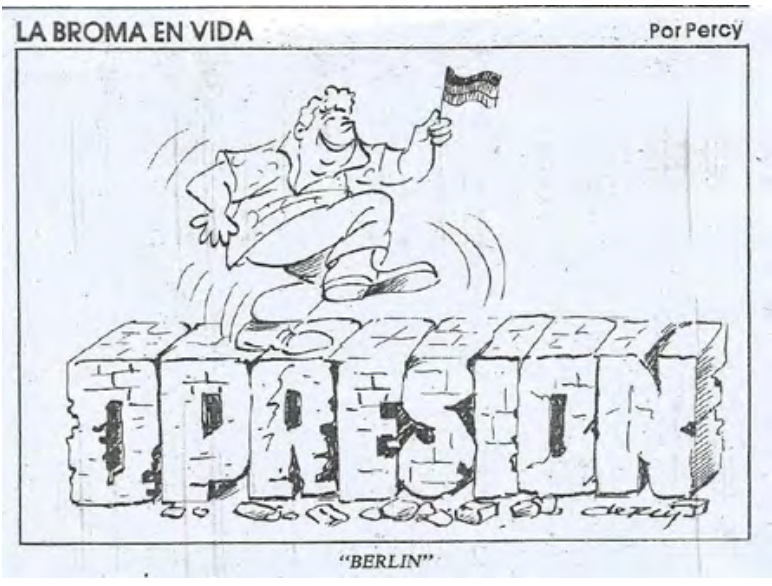

Imagen 2

La Tercera, 12 de noviembre de 1989, p. 3 


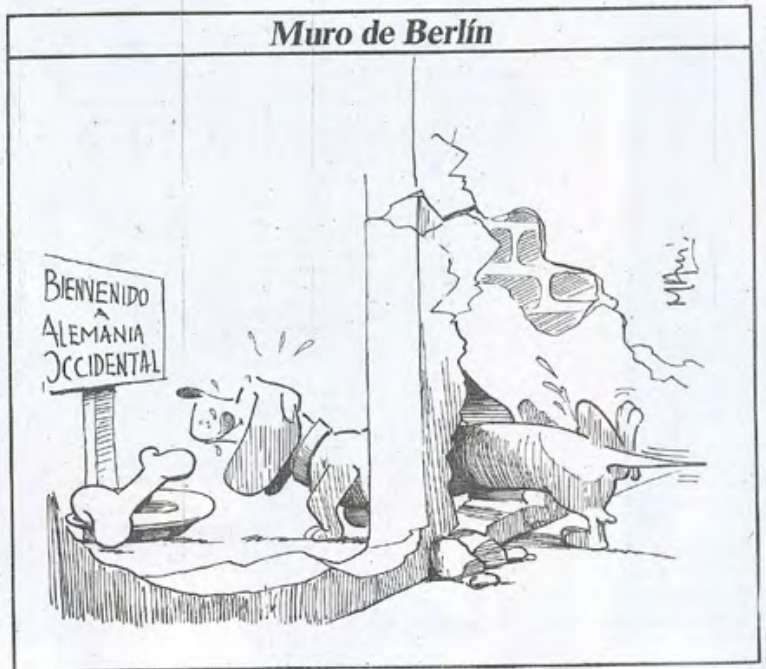

\section{Imagen 3}

La Segunda, 17 de noviembre de 1989, p. 11

El año 1990 se inició con entusiasmo, debido a los cambios internacionales y nacionales. El editorial de Qué Pasa así lo reflejó. Dentro de su balance de los últimos hechos, la revista recogió: «la causa de la libertad está librando sus mejores batallas al culminar la década de los '80. [...] los que ambicionan el poder total no han desaparecido junto con Ceausescu: no son pocos los que anhelan repetir muchas plazas Tiananmen para ahogar los gritos de libertad»; y agregaba: «quizás la voz que vino desde atrás de la cortina de hierro, la prédica del Papa Juan Pablo II [...], la que fue abriendo, en múltiples visitas a su tierra natal, el camino para que tantos pueblos que sufrían la opresión, hoy puedan aspirar a la dignidad». Más tarde, el mismo editorial sentenciaba que, al iniciar la década, Chile daba un ejemplo de «una perfecta transición democrática [...] Esta ha sido posible gracias a la inalterable decisión de las Fuerzas Armadas y del presidente Pinochet, de dar cabal cumplimiento al itinerario institucional y a la aplicación de una sana política económica» ${ }^{77}$. Para la revista, los cambios en Europa del Este

77 «Bienvenida a los ‘90» (Editorial), Qué Pasa, Santiago, No. 978, enero de 1990, p. 3. 
habían sido influenciados por las palabras del Papa Juan Pablo II en Polonia, y ofrecía, a la vez, su contraste con los cambios conducidos desde el Estado chileno por el general Pinochet. Sin lugar a duda, una interpretación desde una posición más conciliadora y conservadora; se trata de otro enfoque de los acontecimientos internacionales y locales.

Los primeros meses de 1990 también sirvieron de escenario para abrir el debate sobre un tema en ciernes: la reunificación alemana, que despertaba, por igual, anhelos entre los germanos del este y el oeste, como los resquemores en las potencias URSS, Reino Unido, Francia y EE. UU. En medio de ese incomodo asunto, la prensa chilena permanecía atenta. La revista Qué Pasa publicó varios trabajos sobre la posible reunificación alemana. En uno de ellos, el periodista Juan Brito examinó las distintas perspectivas en torno al tema, exponiendo el temor de algunos países a una Alemania fuerte, unida y con peso geopolítico ${ }^{78}$.

Igualmente, la periodista Sara Valdés analizó el panorama internacional luego de los turbulentos cambios de 1989, en especial el recelo que despertaba entre ingleses, franceses y soviéticos, por distintos motivos, la reunificación de las dos Alemanias. Hacia el final de su artículo, Valdés señalaba: «Testigos de una época crucial, los europeos y el resto del mundo miran este proceso con una mezcla de ilusión e incertidumbre ${ }^{79}$. En tan sólo cinco meses, el mundo electoral alemán había cambiado drásticamente; desde la caída del comunismo ortodoxo de Erich Honecker a la victoria de la derechista «Alianza por Alemania», auspiciada por Helmut Kohl, que abría el camino para la reunificación de las dos Alemanias ${ }^{80}$. Al mismo tiempo, Caras también recogía las impresiones sobre los intentos por la reunificación alemana, entre esperanzas y expectativas ${ }^{81}$.

Después de la caída del Muro de Berlín, la preocupación, lejos de extinguirse como una noticia pasajera o momentánea, revistió mayor interés, porque allanó el camino para reflexionar abiertamente sobre los regímenes comunistas. Qué Pasa se preguntaba sobre qué pasaría con esas ge-

78 Juan Brito, «Cuarenta años después», Qué Pasa, Santiago, No. 980, enero de 1990, pp. 42-43.

79 Sara Valdés, «El mundo en «revolución», Qué Pasa, Santiago, No. 978, enero de 1990, p. 11.

${ }^{80}$ Sara Valdés, «Aufwiedersen comunismo», Qué Pasa, Santiago, No. 989, febrero de 1990 , p. 41.

81 Carolina García-Huidobro, «Somos alguien nuevamente», Caras, Santiago, No. 50, 14 de marzo de 1990, p. 
neraciones nacidas y criadas dentro de un «sistema totalitario». A lo largo del texto, se observaba con una mezcla de optimismo y escepticismo el futuro cercano, a raíz de las reflexiones e interrogantes en varios países de Europa oriental con respecto a las temidas y odiadas fuerzas de seguridad, como la Stasi en la RDA. En una mirada paralela con la realidad chilena, la revista señalaba: «y aunque este dilema existe en todas las sociedades que vuelven a la democracia, incluido Chile, en el caso de Europa oriental es más complejo aún. En total, medio millón de hombres participó directamente en los aparatos represivos de esta región» ${ }^{82}$. La cuestión era clara, ¿Qué hacer con esos cuerpos en democracia? La revista establecía una analogía entre el proceso que estaba viviendo Europa del Ese y Chile, ambas con la misma tarea pendiente.

Qué Pasa recogía las interrogantes en torno a tres regímenes comunistas que parecían inalterados, refiriéndose a los treinta y un años en el poder de Fidel Castro en Cuba, los cuarenta y dos de Kim II Sung en Corea del Norte, y los siete Ramiz Alia en Albania ${ }^{83}$. En otro artículo, en la misma línea, concluía: «en estos pequeños y aislados reductos ideológicos el vocablo «cambio» no se pronuncia, el mundo gira. Y lo hace a tal velocidad que tarde o temprano, aunque sea a regañadientes, esta trilogía de mandatarios tendrá que encarar el nuevo curso de la civilización. Ya sea empujados por la presión internacional o - lo más probable - desde sus propias tierras, Castro, Kim y Alia tendrán que renovarse o morir» ${ }^{84}$. Tres decenios después, el paso del tiempo pareció demostrar que esos regímenes se «renovaron», más que falleceron.

Paralelo a la percepción del mundo de la prensa, resulta interesante el testimonio del diplomático Jaime Lagos, que presenció los hechos. Lagos, en ese entonces, negociaba la apertura de un consulado chileno en la RDA. Estas fueron sus impresiones: «Miles de berlineses festejaban con una alegría casi incontenible. Era un verdadero carnaval con miles de botellas de cerveza y champaña que yacían sobre el suelo» ${ }^{85}$. Las palabras del diplomático coinciden con los medios chilenos respecto a la euforia experimentada en ese momento por los berlineses y la sensación de intriga por lo que estaba aconteciendo.

82 Sara Valdés, «Hijos del régimen», Qué Pasa, Santiago, No. 990, marzo de 1990, p. 41.

83 J.I.B., «Los que quedan», Qué Pasa, Santiago, No. 978, enero de 1990, p. 11.

${ }^{84}$ Sara Valdés y Cristina Ferrer, «Y quedan tres», Qué Pasa, Santiago, No. 991, abril 1990, p. 43.

85 Lagos, 2008, p. 134. 
Por último, queda claro que las impresiones y opiniones sobre el muro fueron variadas en la mirada chilena. Si bien la mayor parte de los políticos y columnistas se refirieron a la caída del muro berlinés como un triunfo de la libertad, eso no impidió que brotaran temores sobre el destino del comunismo en Cuba y Chile. Las revistas chilenas también debatieron los temas pendientes en la agenda internacional, como los regímenes comunistas sobrevivientes y el proceso de reunificación alemana. La trascendencia del muro, por la división que representó, sirvió de inspiración a dos literatos chilenos contemporáneos. Jorge Edwards narró en El Anfitrión ${ }^{86}$ la representación de personajes divididos por aquella muralla, mientras que Roberto Ampuero relató en Detrás del Muro $^{87}$ las repercusiones, personales e ideológicas, del mundo que encerraba el muro berlinés.

\section{Consideraciones finales}

Desde el punto de vista historiográfico, todavía son escasos los trabajos sobre las revoluciones de 1989 en Chile. La revisión sistemática de los diarios y revistas chilenos permiten aproximarse a la percepción y mirada de los acontecimientos contemporáneos. De este modo, la prensa representa una mirada local de los sucesos mundiales y sus repercusiones inmediatas expresada a través de los editoriales, los artículos de opinión, los reportajes periodísticos, la caricatura, y la recolección de diversos testimonios, tanto de políticos como de ciudadanos comunes. Su análisis y confrontación con otras fuentes documentales y audiovisuales constituyen un valioso recurso para acercarse al impacto que generaron las revoluciones europeas-orientales de 1989 en Chile.

A pesar de la importancia que le dio la prensa chilena a las revoluciones de 1989, esta se nutrió, principalmente, de agencias de noticias internacionales y la reproducción de algunos artículos para analizar los cambios políticos en Polonia, Hungría, Bulgaria y Checoslovaquia, esto podría explicarse por las distancias geográficas, el costo de la cobertura directa (con su propio equipo de periodistas) y la rapidez de los acontecimientos. En particular, la figura de Lech Walesa resultó objeto de aten-

\footnotetext{
${ }^{86}$ Edwards, 1997.

87 Ampuero, 2014.
} 
ción para los diarios chilenos, al punto que El Mercurio envió un periodista a cubrir su visita a Estados Unidos. El discurso informativo de la prensa chilena por los procesos en Europa oriental parece evidenciar una combinación de asombro, escepticismo y optimismo, debido al carácter masivo y pacífico de las movilizaciones ciudadanas y el derrumbe paulatino del sistema comunista en cada país.

Las revoluciones de Europa oriental tuvieron un relevante impacto en la percepción de los principales actores políticos. Por un lado, el general Augusto Pinochet y el círculo de civiles cercanos a su gobierno, robustecieron su postura antimarxista, al considerar que el derribo del Muro de Berlín reafirmaba su convicción sobre el fracaso de esa ideología. Por otro lado, los políticos de oposición, como los democratacristianos (DC), vislumbraron un símil en las situaciones de Europa del Este y Chile, al observar el fin de sistemas políticos de visos autoritarios, lo que despertaba el entusiasmo por los cambios democráticos. Finalmente, se hallaba el grupo de izquierda, encabezado por el partido comunista (PC), que parecía tomar una actitud estupefacta y negacionista ante la ola de transformaciones se sacudió el bloque socialista.

La fractura de la RDA, la apertura del Muro de Berlín y la caída de Nicale Ceausescu en Rumania constituyeron los temas de mayor atención por parte de los diarios y revistas chilenos, lo que podría explicarse, en parte, por haber sido de los últimos cambios producidos en 1989, entre noviembre y diciembre, pero también por el simbolismo de la muralla berlinesa como sinónimo de división del mundo en bloques y «frontera» material de la Guerra Fría. De esta manera, La Segunda contó con reportajes desde Berlín para cubrir los hechos, mientras que las revistas dedicaron análisis extensos a los cambios políticos en la RDA y Rumania.

La prensa chilena reflejó también sus posiciones editoriales con respecto a los procesos de democratización en Europa oriental. La Nación y El Mercurio se mostraron más críticos con los regímenes comunistas, mientras que La Tercera y La Segunda destacaron las movilizaciones ciudadanas como acciones populares y pacíficas, que propiciaron los cambios políticos. En cambio, El Siglo y Pluma y Pincel, medios abiertamente de izquierda, optaron, en principio, por desconocer los procesos de cambios, señalándolos como matrices de la prensa internacional, para luego pasar a disminuir sus alcances políticos. Los contrastes presentes dentro de la prensa constituyen un reflejo de las distintas miradas políticas y sociales de un Chile en transición, que observaba en los procesos europeos un espejo de los cambios que estaba experimentando el país. 
En la mayoría de las percepciones sobre las revoluciones orientales, se evidencia una mayor claridad en lo que respecta a la caída del Muro de Berlín, por sobre los casos o los movimientos de los otros países. Esto pudría explicarse por lo simbólico de la caída del muro como signo de opresión, como también por ser el proceso más dramático (simbolizaba la Guerra Fría en sí misma, la bipolaridad y la frontera de esos dos mundos o esferas de influencia). Quedan abiertas dudas, preguntas o conjeturas con respecto a algunas ausencias o silencios (voluntarios o no) de distintos actores políticos. En esto podría influir el proceso de aislamiento internacional, la presencia de censura o autocensura y la coyuntura político electoral.

Por último, resultan particularmente destacables las posturas de dos medios con miradas distintas, que permiten evidenciar lecturas diferentes en torno al Muro de Berlín. Por un lado, El Siglo, con una mirada marcadamente política, pareció mostrar tres líneas: uno, la exaltación del modelo soviético; dos, el silencio ante el Muro de Berlín; tres, la atingencia de la coyuntura política electoral chilena. Por otro lado, La Segunda, preocupado por el periodismo profesional, fue uno de los diarios que envío su propio equipo reporteril a Alemania para realizar una cobertura especial, y que aportó visiones sobre el desarrollo de la vida cotidiana en los días posteriores de la apertura del muro. En todo caso, la percepción de la prensa chilena muestra que hubo matices, no son monocromáticos, en las posturas.

\section{Fuentes Consultadas}

\section{Periódicos y Revistas}

El Mercurio (Chile) 1989.

El Siglo (Chile) 1989.

La Época (Chile) 1989.

La Nación (Chile) 1989.

La Segunda (Chile) 1989.

La Tercera (Chile) 1989.

Caras (Chile) 1989-1990.

Hoy (Chile) 1989-1990.

Pluma y Pincel (Chile) 1989-1990.

Qué pasa (Chile) 1989-1990. 


\section{Bibliografía}

ACUÑA, Fernando (Ed.). Los primeros 50 años de la televisión chilena. Santiago, Impresión Printer, 2007.

Ampuero, Roberto, Detrás del muro. Novela de mi memoria imprecisa, Penguin, Santiago, 2014.

Antoszewski, Andrzej, Fredo Arias King, Ewa Bujwid-Kurek, Leszek Balcerowicz (ed), Del autoritarismo a la democracia: La experiencia polaca, Lech Walesa Institute, Buenos Aires, 2014.

AYlwin, Patricio, El reencuentro de los demócratas, FCE, Santiago, 2018.

BozóKI, András (ed.), The Roundtable Talks of 1989: The Genesis of Hungarian Demcoracy, Central European University, Budapest, 2002.

Brahm, Enrique, Los Brahm. De Werl a Puerto Montt. Una familia de inmigrantes westfalianos 1864-2014, Bicentenario, Santiago, 2015.

Brahm, Enrique, Preparados para la Guerra. Pensamiento militar chileno bajo influencia alemana, 1885-1930, UC, Santiago, 2002.

CAmpos, Sergio. La voz de la radio está llamando: mis memorias, Santiago, Penguin, 2016

Cough, Roger, A Good Comrade: János Kádar, Communism and Hungary, Tauris, London, 2006.

DIE TODESOPFER AN DER BERLINER MAUER 1961-1989: EIN BIOGRAPHISCHES HAND$B U C H$, Ch. Links Verlag, Berlin, 2009.

DitTus, Rubén y Erna Ulloa. «Cartografía del cine político chileno. Entre el discurso político y la retórica audiovisual», Anàlisi: Quaderns de Comunicació i Cultura, No. 56, 2017, pp. 33-47.

DoOner, Patricio, Periodismo y política a a prensa de derecha e izquierda, 19701973. Santiago, Ed. Andante, 1989.

Edwards, Jorge, El Anfitrión. Alfaguara, Madrid, 1997.

FANJul, Enrique, «Memoria de Tiananmen: 20 años de la revuelta estudiantil», Política Exterior, 129, 2009, pp. 29-34.

Fermandois, Joaquín, «De una inserción a otra: Política exterior de Chile, 19661991», Estudios Internaciones, 96, 1991, pp. 433-455.

FERMANDOIS, Joaquín, Mundo y fin de mundo. Chile en la política mundial 19002004, UC, Santiago, 2004.

Fulbrook, Mary, Interpretations of the Two Germanies, 1945-1990, MacMillan, New York, 2000.

Fürst, Juliane, Silvio Pons and Mark Selden (eds.), The Cambridge History of Communism, University of Cambridge, Cambridge, 2017.

GAdDIS, John Lewis, Nueva historia de la Guerra Fría, FCE, México, 2012.

GARAY VERA, Cristián y Karin Willicke. «El Mercurio y el 11 de septiembre del 73», Universum, 22(1), 2007, pp. 318-339. 
Garzón, Dionisio, El Muro de Berlín. Final de una época histórica, Marcial Pons, Madrid, 2013.

Gorbachov, Mijaíl. Perestroika: nuevas ideas para nuestro país y el mundo entero, Emecé, Buenos Aires, 1987.

Gyarmati, György and Tibor Valuch, Hungary under Soviet Domination: 1944-1989, Social Science Monographs, Boulder, 2009.

HertLE, Hans-Hermann, Die Berliner Mauer - Monument des Kalten Krieges, Ch. Links Verlag, Berlin, 2007.

HuneEus, Carlos. El régimen de Pinochet. Santiago: Sudamericana, 2000.

Kalinovsky, Artemy and Craig Daigle (eds.), The Routledge of the Cold War, Routledge, New York, 2014.

Kemp-Welch, Anthony, Poland under Communism: A Cold War History, Cambridge University, Cambridge, 2008.

KotKIN, Stephen and Jan Gross, Uncivil Society: 1989 and the Implosion of the Communist Establishment, The Modern Library, New York, 2009.

KREBS, Andrea (ed.), Los alemanes y la comunidad chileno-alemana en la historia de Chile, Liga Chileno-Alemana, Santiago, 2001.

Lagos, Jaime, Al servicio de Chile. Crónicas de un diplomático, Universidad Finis Terrae, Santiago, 2008.

LeFFler, Melvyn and Odd Arne Westad (eds.), The Cambridge History of the Cold War, University of Cambridge, Cambridge, 2010.

MAIER, Charles, Dissolution: The Crisis of Communism and the End of East Germany. Princeton University, New Jersey, 1997.

Major, Patrick, Behind the Berlin Wall: East Germany and the Frontiers of Power, Oxford University, Oxford, 2010.

Mavrokordatos, Pete, Stan Stascinsky and Andrew Michael, «Germany: Twenty Years After The Union», IBERJ, 9.4, 2010, pp. 113-124.

McDermott, Kevin and Matthew Stibbe (eds.), The 1989 Revolutions in Central and Eastern Europe: From Communism to Pluralism, Manchester University, Manchester, 2013.

Medina, Cristián; ERNa UlloA, Gustavo Gajardo y Ángel Soto, «El huésped (in) esperado. Erich Honecker en la Embajada de Chile en Moscú». en LILÓN, Domingo y Máté Deák (eds.), Encuentros. Europa - Iberoamérica en un mundo globalizado, Universidad de Pécs, Budapest, 2018.

MedinA, Cristián y Gustavo Gajardo, «De apátrida errante a vecino santiaguino. El «Caso Honecker» desde las fuentes oficiales (1991-1994)», Tzintzun, 65, 2017, pp. 260-284.

MEDINA, Cristián y Gustavo Gajardo, «Entre protectores y opositores: Labor política frente al caso Honecker», Revista de Ciencia Política, 36.3, 2016, pp. 731-748.

MuÑOZ, Jorge, «Políticas centrales, inmigración alemana y gente menuda en la frontera decimonónica. Valdivia, La Unión y Osorno (1840-1890)», RHSM 12, 2008, pp. 23-51. 
OsSANDÓn, Fernando y Sandra Rojas, La Época y Fortín Mapocho. El primer impacto, Santiago, ECO-CEDAL, 1989.

PaCzKowsKi, Andrzej, Revolution and Counterrevolution in Poland, 1980-1989: Solidarity, Martial Law, and End of Communism in Europe, University of Rochester, New York, 2015.

PowASKI, Ronald, La Guerra Fría. Estados Unidos y la Unión Soviética, 1917-1991, Crítica, Barcelona, 2000.

RiQuelme, Alfredo. Rojo atardecer. El comunismo chileno entre dictadura y democracia. Santiago: DIBAM, 2009.

RIVERA, Carla, «La verdad está en los hechos: Una tensión entre objetividad y oposición. Radio Cooperativa en dictadura», Historia, No. 41, 2008, pp. 79-98.

RoJAS, Francisco, «Chile: cambio político e inserción internacional 1964-1997, Estudios Internacionales, 119-120, 1997, pp. 376-406.

RuBio, Pablo, Los civiles de Pinochet: La derecha en el régimen militar chileno, 1983-1990, DIBAM, Santiago, 2013.

SAN Francisco, Alejandro y Ángel Soto (eds.), Camino a La Moneda: Las elecciones presidenciales en la historia de Chile 1920-2000, Bicentenario, Santiago, 2005.

Santa CRuz, Eduardo, Prensa y sociedad en Chile, siglo XX, Santiago, Ed. Universitaria, 2015.

Soto, Ángel, El Mercurio y la difusión del pensamiento político económico liberal 1955-1970, Santiago, Bicentenario, 2003.

SмIтH, Stephen (ed.), The Oxford Handbook of the History of Communism, University of Oxford, Oxford, 2014.

TSMAnEAnU, Vladimir (ed.), The Revolutions of 1989, Routledge, London, 1999.

Ulianova, Olga. «El exilio comunista chileno 1973-1989», Estudos Ibero-Americanos, 39(2), 2013, pp. 212-236.

Ulianova, Olga y Alfredo Riquelme (Ed.). Chile en los archivos soviéticos 1922.1991, Santiago, DIBAM - LOM - USACH, 2005.

VeEn, Hans-Joachim, Peter März, Franz-Josef Schlichting, Die Folgen der Revolution: 20 Jahre nach dem Kommunismus, Böhlau Verlag, Köln,2010.

Westad, Odd Arne, The Cold War: A World History, Galaxia Gutenberg, Barcelona: 2018.

\section{Datos de los autores}

Froilán Ramos Rodríguez Doctor y Magíster en Historia por la Universidad de los Andes (Chile), Magíster Scientiarum en Historia, Universidad Centro-Occidental Lisandro Alvarado (UCLA, Venezuela), Profesor de Geografía e Historia, Universidad Pedagógica Experimental Libertador (UPEL, Venezuela). Ha sido profesor e investigador en universidades y centros en Venezuela y Chile. Actualmente, es 
Profesor Asistente del Departamento de Historia y Geografía, Universidad Católica de la Santísima Concepción (UCSC). Es autor de Travesía de la esperanza. La inmigración portuguesa en Barquisimeto (2018), y artículos en revistas.

Constanza Arias Arias. (connirandom@gmail.com), Licenciada en Educación y Profesora de Historia, Geografía y Educación Cívica por la Universidad de Las Américas (UDLA, Chile). Orcid: https://orcid.org/0000-0002-5904-090X 